\title{
Transformation and $\mathrm{pp} 60^{\mathrm{v}-\mathrm{src}}$ Autophosphorylation Correlate with SHC-GRB2 Complex Formation in Rat and Chicken Cells Expressing Host-Range and Kinase- active, Transformation-defective Alleles of v-src
}

\author{
Michael F. Verderame, ${ }^{*+\ddagger}$ Jun-Lin Guan, ${ }^{\S}$ and \\ Kathleen M. Woods Ignatoski*\|
}

${ }^{*}$ Cell and Molecular Biology Graduate Program, ${ }^{+}$Department of Microbiology and Immunology, The Pennsylvania State University College of Medicine, Hershey, Pennsylvania 17033; and ${ }^{\S}$ Department of Pathology, New York State College of Veterinary Medicine, Cornell University, Ithaca, New York 14853

Submitted September 8, 1994; Accepted May 17, 1995

Monitoring Editor: Joseph Schlessinger

\begin{abstract}
The biochemical properties of several $\mathrm{pp} 60^{\mathrm{v}-s r c}$ substrates believed to participate in $s r c$-mediated transformation were examined in cells expressing a kinase-active, transformation-defective v-src allele (v-src-F172 $\Delta / \mathrm{Y} 416 \mathrm{~F})$ and its parental allele, v-src-F172 $\Delta$, a host-range-dependent allele that transforms chicken cells to a fusiform morphology, but does not transform rat cells. Because $\mathrm{pp} 60^{\mathrm{v}-\mathrm{src}-\mathrm{F} 172 \Delta}$ is dependent on autophosphorylation for transforming ability, these alleles provide a unique opportunity to examine the role of pp $60^{\mathrm{v}-s r c}$ autophosphorylation in regulating substrate interactions. Increased $\mathrm{pp} 125^{\mathrm{FAK}}$ tyrosine phosphorylation and high levels of $\mathrm{pp} 60^{\mathrm{v}-s r c}$-associated phosphotidylinositol-3' kinase activity were detected specifically in chicken cells exhibiting round, refractile transformation but not in cells transformed to a fusiform morphology. Increased pp $125^{\text {FAK }}$ kinase activity, but not increased pp $125^{\text {FAK }}$ tyrosine-phosphorylation correlated with $\mathrm{pp} 60^{\mathrm{v}-s r c}$ autophosphorylation and increased anchorage-independent growth. Thus, pp125 $5^{\mathrm{FAK}}$ and $\mathrm{PI} 3^{\prime} \mathrm{K}$ may participate in morphological transformation by v-src. Furthermore, association of phosphorylated SHC with the adapter GRB2 correlated with increased anchorage-independent growth (and autophosphorylation) in both rat and chicken cells independent of the morphological phenotype induced. Therefore, host-range dependence for transformation may be regulated through association of SHC with GRB2, thus implicating SHC as a crucial substrate for src-dependent transformation.
\end{abstract}

\section{INTRODUCTION}

The mechanism by which the protein tyrosine kinase $(\mathrm{PTK})^{1} \mathrm{pp}^{6} 0^{\mathrm{v}-\mathrm{src}}$ transforms cells into a neoplastic state has not been elucidated despite intensive studies (reviewed in Parsons and Weber, 1989). A large number of cellular proteins, both structural and enzymatic, are

\footnotetext{
$\ddagger$ Corresponding author.

" Present address: Howard Hughes Medical Institute, University of Michigan Medical School, Ann Arbor, MI 48109.

${ }^{1}$ Abbreviations used: $F$, phenylalanine; PAGE, polyacrylamide gel electrophoresis; $\mathrm{PI} 3^{\prime} \mathrm{K}$, phosphatidylinositide-3' kinase; P-Tyr, phosphotyrosine; SDS, sodium dodecyl sulfate; $\mathrm{SH} 2$, src homology region 2; PTK, protein tyrosine kinase; $Y$, tyrosine.
}

phosphorylated on tyrosine in response to $\mathrm{pp} 60^{\mathrm{v}-s r c}$, and many of these proteins have been suggested to participate in the process of transformation.

Previous studies in our laboratory identified a series of $\mathrm{v}$-src alleles that transform both chicken and rat cells (wild-type [wt] v-src and v-src-Y416F), transform only chicken cells but not rat cells (v-src-F172 $\Delta$ ) (Varmus et al., 1981; Verderame et al., 1989), or cannot transform either chicken or rat cells (v-src-F172 $\Delta$ / Y416F) (Woods and Verderame, 1994). Unlike wt v-src or v-src-Y416F, which both transform chicken cells to a round refractile morphology, v-src-F172 $\Delta$ transforms chicken cells to a fusiform morphology. F172, a con- 
served residue found in all but one known srchomology-2 (SH2) domain (Koch et al., 1991), is predicted to be required for proper folding of the SH2 domain but not to have a direct interaction with phosphotyrosine (P-Tyr)-containing peptides (Waksman et al., 1992). Each of these alleles encodes a protein that retains kinase activity, although the transformation-defective allele $\mathrm{v}$-src-F172 $/ \mathrm{Y} 416 \mathrm{~F}$ has significantly less activity that wt (Woods and Verderame, 1994). The ability of mutant v-src alleles to break correlations between phosphorylation of a particular substrate and transforming ability is a well established method of diverting attention away from irrelevant substrates and maintaining a focus on potentially relevant substrates (Parsons and Weber, 1989).

This report describes the biochemical analysis of several potentially relevant $\mathrm{pp} 60^{\mathrm{v}-s r c}$ substrates in both rat and chicken cells expressing host-range or transformation-defective v-src alleles. Because there is strong evidence that $s r c$-dependent transformation requires p21 ${ }^{\text {ras }}$ activity (Smith et al., 1986), two regulators of $\mathrm{p} 21^{\text {ras }}$ were examined in the present study. The phosphorylation state of $\mathrm{p} 42^{\mathrm{SHC}}, \mathrm{p} 56^{\mathrm{SHC}}$, and $\mathrm{p}^{\mathrm{SHC}}$ (collectively referred to as $\mathrm{SHC}$, an upstream activator of p21 ras $)$ and p120 ras-GAP (a negative regulator of $\mathrm{p} 21^{\text {ras }}$ ) were examined; proteins that physically associate with SHC and p120 ras-GAP were also examined ( $\mathrm{p} 21^{\text {ras }}$ activation is reviewed in Pronk and Bos, 1994). Because many downstream effectors in signaling pathways bind stably to their upstream activators, two substrates that form stable complexes with pp60 v-src were also examined: pp125 $5^{\mathrm{FAK}}$ (Xing et al., 1994) and phosphatidylinositide-3'-kinase (PI3'K; Fukui and Hanafusa, 1989). Finally, the P-Tyr state and subcellular localization of the F-actin binding protein cortactin was determined (Wu et al., 1991). Recent observations that the GRB2/SOS complex is associated with pp $125^{\mathrm{FAK}}$ in v-src-transformed cells (Schlaepfer et al., 1994), and that PI3'K activity is associated with activated pp $125^{\mathrm{FAK}}$ (Chen and Guan, 1994b) highlight the ongoing interest in the role these substrates serve in the regulation of proliferation.

Results presented in this report suggest hostrange dependence for transformation is regulated at the level of the SHC/GRB2 interaction, indicating the importance of SHC phosphorylation in src-mediated transformation, and they demonstrate a correlation between anchorage-independent growth, increased $\mathrm{p} 125^{\mathrm{FAK}}$ kinase activity, and increased pp60 ${ }^{\mathrm{v}-s r c}$-associated $\mathrm{PI}^{\prime} \mathrm{K}$ activity. Regulation of these various biochemical responses by the pp $60^{\mathrm{v}-s r c}$ $\mathrm{SH} 2$ domain, and by $\mathrm{pp} 60^{\mathrm{v}-s \mathrm{rc}}$ autophosphorylation is discussed.

\section{MATERIALS AND METHODS}

\section{Cell Culture and $v$-src Alleles}

All cell culture, DNA transfections, and viral reverse transcriptase assays were performed as previously described (Verderame et al., 1989; Woods and Verderame, 1994; Verderame and Varmus, 1994). The v-src alleles used in this study (wt v-src, v-src-Y416F, v-src$\mathrm{F} 172 \Delta$, and $v$-src-F172 $\Delta / \mathrm{Y} 416 \mathrm{~F}$ ) were cloned into the replication competent avian retroviral vector RCAS (Hughes et al., 1987). Rat cell lines Rat-1, B31, and L (expressing no v-src, wt v-src, or v-srcF172 $\Delta$, respectively) have been previously described (Oppermann et al., 1981; Varmus et al., 1981; Verderame et al., 1989). Rat-1 and L have normal growth properties, whereas B31 is transformed by all parameters examined.

\section{Immunoprecipitations}

Immunoprecipitations for p120 ras-GAP (Pronk et al., 1992), cortactin (Wu et al., 1991), pp60 v-src (Parker et al., 1984), and pp125 $5^{\text {FAK }}$ (Guan and Shalloway, 1992) were performed as described previously using the following monoclonal antibodies: B4F8 for p120 ras-GAP (Santa Cruz Biotechnology, Santa Cruz, CA); 4F11 for cortactin (a gift of J. Thomas Parsons, University of Virginia, Charlottesville, VA); monoclonal antibody 127 for pp60 6 -src (a gift of Joan Brugge, Ariad Pharmaceuticals, Cambridge, MA); and anti-FAK serum for pp125 ${ }^{\mathrm{FAK}}$ (Xing et al., 1994). SHC and GRB2 were precipitated after cell lysis in buffer containing $50 \mathrm{mM}$ Tris (pH 7.5), $150 \mathrm{mM} \mathrm{NaCl}, 1 \%$ Nonidet P-40, $0.25 \%$ sodium deoxycholate, and 2 mM EGTA using rabbit polyclonal antiserum \#S14630 or mouse monoclonal antibody \#G16720, respectively (Transduction Laboratories, Lexington, KY). Although chicken SHC proteins migrate faster than their mammalian counterparts, we have retained the $\mathrm{p} 46^{\mathrm{SHC}}, \mathrm{p} 52^{\mathrm{SHC}}$, and $\mathrm{p} 66^{\mathrm{SHC}}$ designations (Crowe et al., 1994).

\section{pp125 ${ }^{\text {FAK }}$ Kinase Assays}

Kinase assays were performed as described previously (Guan and Shalloway, 1992). Reaction products were separated on $7.5 \%$ polyacrylamide gels containing sodium dodecyl sulfate (SDS). The amount of ${ }^{32} \mathrm{P}$ transferred to substrate was quantitated by scintillation.

\section{Protein Blots}

Proteins from whole cell lysates or from immunoprecipitations were separated on $7.5 \%$ or $10 \%$ polyacrylamide gels containing SDS and transferred to nitrocellulose. P-Tyr-containing proteins in $\mathrm{p} 12 \mathrm{O}^{\text {ras- }}$ GAP immunoprecipitations were detected by PY20 anti-P-Tyr antibody (ICN Pharmaceuticals, Costa Mesa, CA) followed by alkaline phosphatase-conjugated secondary antibodies. All other antigens were detected with horseradish peroxidase-conjugated secondary antibodies and Renaissance chemiluminescence reagents (DuPont NEN, Boston, MA).

\section{Immunofluorescence}

Indirect immunofluorescence for cortactin was performed as described previously (Wu et al., 1991) using monoclonal antibody 4F11. Briefly, cells were fixed in 3\% paraformaldehyde and permeabilized in $0.4 \%$ Triton X-100, then incubated with $4 \mathrm{~F} 11$ antibody for $1 \mathrm{~h}$ at $25^{\circ} \mathrm{C}$. The excess antibody was washed away in phosphatebuffered saline ( $\mathrm{pH} 7.4)$, and the cells were incubated with fluorescein-conjugated goat anti-mouse IgG antibody. Subcellular localization of cortactin was visualized by fluorescent microscopy using a Nikon Labphot-2 (Melville, NY). 


\section{PI3'K Assays}

pp60-src immunoprecipitations were washed as described previously (Verderame et al., 1989) then subjected to PI3'K assays. Immunoprecipitates were resuspended in PI3'K assay buffer $(20 \mathrm{mM}$ Tris, pH 7.4; $100 \mathrm{mM} \mathrm{NaCl} ; 10 \mathrm{mM} \mathrm{MgCl} ; 0.5 \mathrm{mM}$ EGTA; $120 \mu \mathrm{M}$ adenosine). Lipid micelles were prepared by mixing phosphotidylinositol and phosphotidylserine $1: 1(\mathrm{v} / \mathrm{v})$ and drying them in a stream of $\mathrm{N}_{2}$. The lipids were reconstituted in $20 \mathrm{mM} \mathrm{N}$-2-hydroxyethylpiperazine- $N^{\prime}$-2-ethanesulfonic acid, pH 7.4, and $1 \mathrm{mM}$ EDTA to $2 \mu \mathrm{g} / \mu \mathrm{l}$, and then sonicated for $5-10 \mathrm{~s}$ at $25^{\circ} \mathrm{C}$ using a probe sonicator. Ten micrograms of lipids were added to the immunoprecipitates and the mixture was heated to $30^{\circ} \mathrm{C}$. Reactions were started by the addition of $10 \mu \mathrm{Ci}\left[\gamma_{-}{ }^{32} \mathrm{P}\right] \mathrm{ATP}$ and $100 \mathrm{nM}$ ATP and allowed to proceed for $10 \mathrm{~min}$ at $30^{\circ} \mathrm{C}$. The reactions were stopped by the addition of $1 \mathrm{~N} \mathrm{HCl}$. Reaction products were extracted once in 1:1 (v/v) $\mathrm{CHCl}_{3}$ :methanol, once in $1 \mathrm{~N} \mathrm{HCl}$, and were separated on silica plates as previously described (Walsh et al., 1991). The amount of ${ }^{32} \mathrm{P}$ incorporated into phosphatidylinositol phosphate was quantitated using a Betascope 603 analyzer (Betagen, Waltham, MA). PI3'K directly immunoprecipitated from parallel lysates using rabbit polyclonal antibody \#P13030 (Transduction Laboratories, Lexington, $\mathrm{KY}$ ) was also subjected to a $\mathrm{PI}^{\prime} \mathrm{K}$ assay reaction to provide a standard for phosphatidylinositol phosphorylated on the $3^{\prime}$ position.

\section{RESULTS}

\section{p21 ${ }^{\text {ras }}$-Regulators: Phosphorylation State and Associated Proteins}

SHC. Because SHC is phosphorylated on tyrosine in cells transformed by pp60 ${ }^{\mathrm{v}-s r c}$ (McGlade et al., 1992), and is an upstream activator of $\mathrm{p} 21^{\text {ras }}$, (reviewed in Pronk and Bos, 1994), the phosphorylation state of SHC was examined in chicken and rat cells expressing various mutant $\mathrm{v}$-src alleles. In chicken cells (Figure $1 \mathrm{~A}), \mathrm{p} 56^{\mathrm{SHC}}$ is highly phosphorylated on tyrosine whenever a kinase-active allele of $\mathrm{v}$-src is expressed regardless of whether the cells are transformed (wt

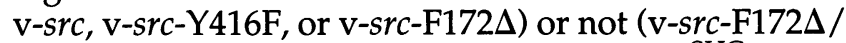
$\mathrm{Y} 416 \mathrm{~F}$ ). Increased phosphorylation of $\mathrm{p} 56^{\mathrm{SHC}}$ is revealed by reduced mobility in SDS-PAGE and by antiP-Tyr probing of the SHC immunoprecipitations. The level of tyrosine phosphorylation on $\mathrm{p} 56^{\mathrm{SHC}}$ is only slightly reduced in nontransformed chicken cells expressing $\mathrm{v}$-src-F172 $\Delta / \mathrm{Y} 416 \mathrm{~F}$ relative to chicken cells transformed by wt v-src even though the specific kinase activity of pp60 $0^{\mathrm{v}-\mathrm{src}-\mathrm{F} 172 \Delta / \mathrm{Y} 416 \mathrm{~F}}$ is almost 20 -fold lower than wt. The phosphorylation status of $\mathrm{p} 66^{\mathrm{SHC}}$ is less clear. Protein blots probed with anti-SHC antibodies reveal that $\mathrm{p} 66^{\mathrm{SHC}}$ steady state levels apparently are reduced in cells expressing a kinase active $\mathrm{v}$-src. This apparent decrease is accompanied by the appearance of a novel band detectable by anti-SHC antibodies (indicated in Figure 1A); this novel band is highly phosphorylated on tyrosine and could represent a phosphorylated form of $\mathrm{p} 66^{\mathrm{SHC}}$ with substantially altered mobility. $\mathrm{p} 42^{\mathrm{SHC}}$ tyrosine phosphorylation is not dramatically altered in any of the cells.

Because tyrosine phosphorylation of SHC can create a binding site for GRB2 (Salcini et al., 1994), the amount of GRB2 in the SHC immunoprecipitates was determined (Figure 1A). GRB2 associated with SHC is easily detectable in cells expressing any of the transforming alleles of $\mathrm{v}$-src, but is only barely detectable in cells expressing the transformation-defective allele $\mathrm{v}$-src-F172 $\Delta / \mathrm{Y} 416 \mathrm{~F}$. It is noteworthy that the hostrange allele v-src-F172 $\Delta$ induces SHC phosphorylation and GRB2 association indistinguishable from that induced by v-src-Y416F; both of these alleles have specific kinase activity about $30 \%$ of wt $\mathrm{v}$-src (Woods and Verderame, 1994), but only v-src-Y416F induces full morphological transformation.

SHC was also immunoprecipitated from rat cells expressing wt v-src or $\mathrm{v}$-src-F172 $\Delta$ (which does not transform rat cells) and was similarly analyzed for tyrosine phosphorylation and GRB2 association. As expected, $556^{\mathrm{SHC}}$ phosphorylated was readily detectable in cells expressing wt $\mathrm{v}$-src, indicated by the decreased mobility and directly revealed by anti-P-Tyr antibodies (Figure 1B). p66 $6^{\mathrm{SHC}}$ was also phosphorylated on tyrosine in transformed rat cells. The level of P-Tyr on p46 ${ }^{\mathrm{SHC}}$ was not altered substantially in either rat or chicken cells expressing any v-src allele. SHC immunoprecipitates from rat cells expressing hostrange v-src-F172 $\Delta$ (which does not transform rat cells) had greatly reduced levels of GRB2 relative to SHC immunoprecipitates from rat cells transformed by wt v-src.

To confirm these results, GRB2 immunoprecipitates from rat cells were probed with anti-P-Tyr and antiSHC antibodies (Figure 2). Tyrosine-phosphorylated p5 $56^{\mathrm{SHC}}$ and $\mathrm{p} 66^{\mathrm{SHC}}$ are specifically detectable in the GRB2 immunoprecipitates from rat cells transformed by wt v-src. In contrast, tyrosine-phosphorylated p42 ${ }^{\mathrm{SHC}}$ is present in GRB2 immunoprecipitates from all rat cell lines.

In summary, the level of GRB2 association with tyrosine-phosphorylated SHC correlated with v-srcdependent transformation in both chicken and rat cells, but the level of SHC tyrosine phosphorylation did not; the host-range allele v-src-F172 $\Delta$ is particularly revealing in this regard.

p120 $0^{\text {ras-GAP. }}$. Because p120 ras-GAP is an in vitro substrate of $\mathrm{pp} 60^{\mathrm{v}-s r c}$ and may be involved in $\mathrm{pp} 60^{\mathrm{v}-s r c}$ transformation (Pronk and Bos, 1994), the P-Tyr content of $\mathrm{p} 120^{\text {ras }-\mathrm{GAP}}$ in the presence of transforming and nontransforming v-src alleles was also studied. Protein blots of $\mathrm{p} 120^{\text {ras-GAP }}$-immunoprecipitates from chicken cells (Figure 3A) and rat cells (Figure 3B) expressing various $\mathrm{v}-s r c$ mutants were probed with anti-P-Tyr antibodies. The P-Tyr content of the precipitated proteins was compared with the steady-state amount of $\mathrm{p} 120^{\text {ras-GAP }}$. (We have consistently detected increased steady state levels of $\mathrm{p} 120^{\text {ras }}$-GAP in chicken cells expressing any v-src gene compared with vectoronly control cells. p120 ras-GAP immunoprecipitations 

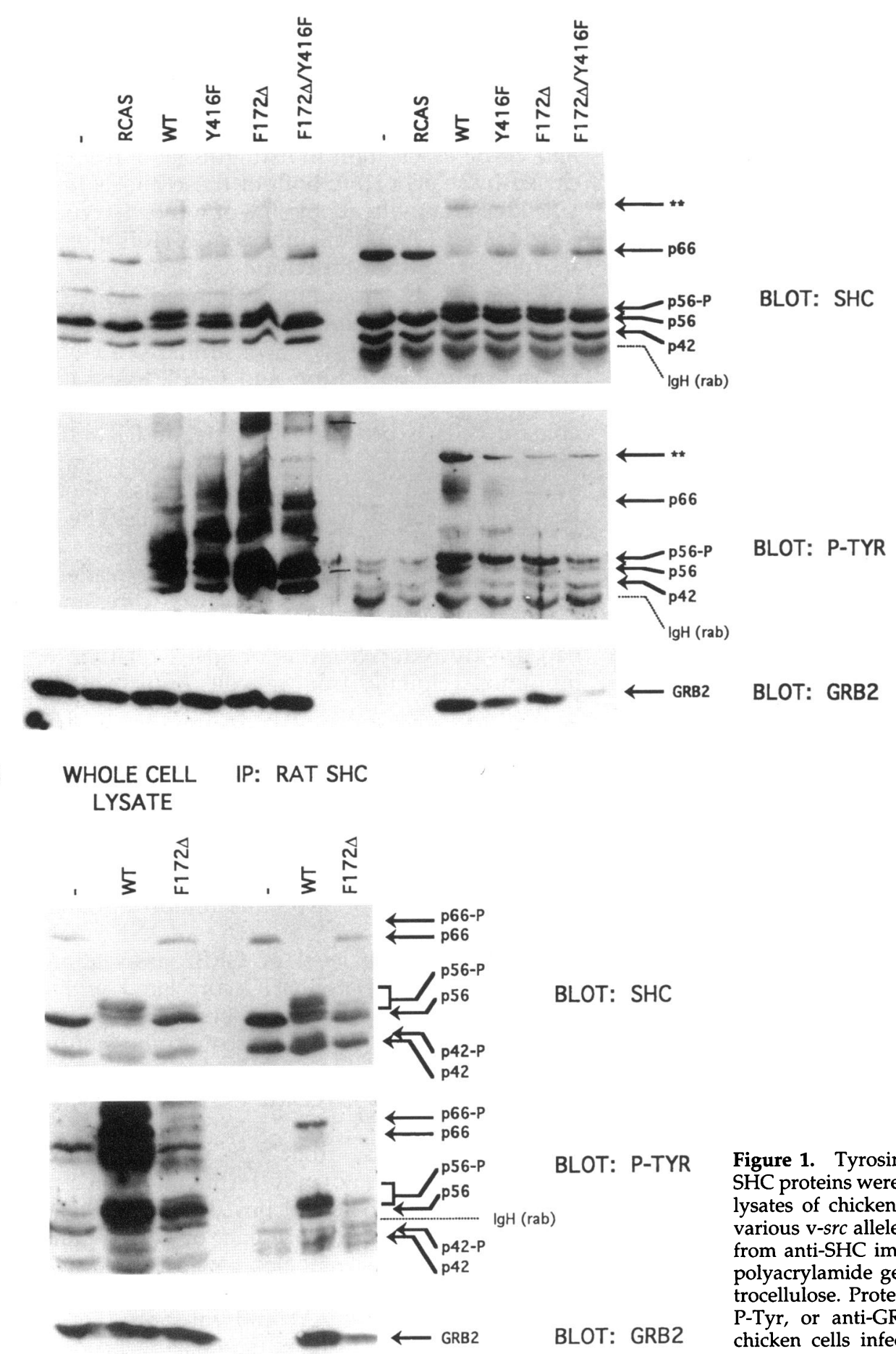

Figure 1. Tyrosine phosphorylation of SHC proteins. SHC proteins were immunoprecipitated from whole cell lysates of chicken cells (A) or rat cells (B) expressing various v-src alleles; proteins from whole cell lysates or from anti-SHC immunoprecipitates were separated on polyacrylamide gels containing SDS and blotted to nitrocellulose. Proteins were detected by anti-SHC, antiP-Tyr, or anti-GRB2 antibodies as indicated. RCAS, chicken cells infected with vector only; "-", control rat cells.

were performed in antigen excess so that each immunoprecipitation had equal amounts of p120 ras-GAP. Thus, the P-Tyr content could be compared directly). In chicken cells, no difference in the P-Tyr content of p120 ras-GAP was detected between cells expressing nontransforming $\mathrm{v}-\mathrm{src}-\mathrm{F} 172 \Delta / \mathrm{Y} 416 \mathrm{~F}$ compared with cells expressing transforming alleles $\mathrm{v}$-src-Y416F or $\mathrm{v}-\mathrm{src}$-F172 $\Delta$; the P-Tyr content of $\mathrm{p} 120^{\text {ras-GAP }}$ from cells 
WHOLE CELL IP: RAT GRB2

LYSATE

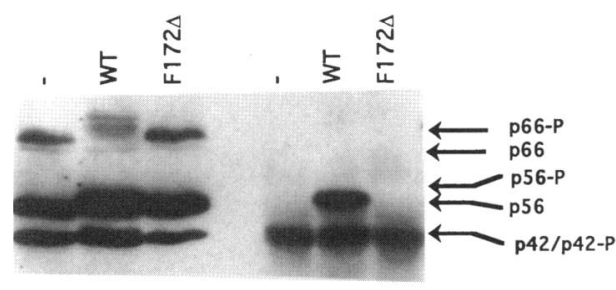

BLOT: SHC

BLOT: P-TYR

BLOT: GRB2

Figure 2. Detection of SHC in GRB2 immunoprecipitates. GRB2 was immunoprecipitated from whole cell lysates of chicken cells expressing various v-src alleles; proteins from whole cell lysates or from anti-GRB2 immunoprecipitates were separated on polyacrylamide gels containing SDS and blotted to nitrocellulose. Proteins were detected by anti-SHC, anti-P-Tyr, or anti-GRB2 antibodies as indicated. RCAS, chicken cells infected with vector only.

expressing wt $\mathrm{v}$-src was slightly higher. The identity of the P-Tyr-containing protein migrating more slowly than p120 ras-GAP was confirmed to be $120^{\text {ras }}$-GAP -associated $\mathrm{p} 190$ by reprobing the anti-P-Tyr blot with an anti-p190 antibody; as expected (given the results of Moran et al., 1991), p190 was co-precipitated only when p120 ras-GAP was tyrosine phosphorylated. Like p120 ras-GAP, p190 tyrosine phosphorylation did not correlate with transformation by v-src. Anti-p62 antibodies were not available to determine the amount of this protein associated with $120^{\text {ras-GAP }}$ in chicken cells, however, p62 phosphorylation levels were similar in cells expressing kinase-active v-src alleles, regardless of the transformed phenotype. When $\mathrm{p} 120^{\text {ras- }} \mathrm{GAP}$ was immunoprecipitated from rat cells expressing v-srcF172 , P-Tyr was undetectable. Also, p62 and p190 phosphorylation levels were greatly reduced relative to proteins from rat cells transformed by wt v-src. Thus, tyrosine phosphorylation of p120 ras-GAP, p190, or p62 is not sufficient for $\mathrm{v}$-src-mediated transformation.

\section{Phosphorylation and Kinase Activity of pp125 $5^{\text {FAK }}$}

pp $125^{\mathrm{FAK}}$ tyrosine kinase activity is increased in response to a variety of stimuli including transformation by v-src (Guan and Shalloway, 1992). Recently it has been shown that autophosphorylation of $\mathrm{pp} 125^{\mathrm{FAK}}$ creates a high affinity binding site for the $\mathrm{pp} 60^{\text {src }} \mathrm{SH} 2$ domain, and that $\mathrm{pp} 60^{\mathrm{src}}$ interacts with $\mathrm{pp} 125^{\mathrm{FAK}}$ via this site (Schaller et al., 1994). These data suggest that pp $60^{\text {sr }}$ and pp $125^{\mathrm{FAK}}$ may cooperate in v-src transformation. Accordingly, both pp $125^{\mathrm{FAK}} \mathrm{P}-\mathrm{Tyr}$ content and kinase activity were examined. Because pp $125^{\mathrm{FAK}}$ P-Tyr content and kinase activity increase in response to cells binding to fibronectin (Guan and Shalloway, 1992), these properties were studied in both attached and suspended cells. pp $125^{\mathrm{FAK}} \mathrm{P}$-Tyr increased in cells expressing $\mathrm{wt} \mathrm{v}$-src or $\mathrm{v}$-src-Y416F compared with vector-only controls. Concomitantly, a slower migrating form of pp125 12 a with vector-only controls, pp125 $5^{\mathrm{FAK}}$ tyrosine phosphorylation was not increased in cells expressing either $\mathrm{v}$-src-F172 $\Delta$ or $\mathrm{v}$-src-F172 $\Delta / \mathrm{Y} 416 \mathrm{~F}$.

Surprisingly, compared with control cells a reproducible threefold increase in pp $125^{\mathrm{FAK}}$ kinase activity was detected in cells transformed to a fusiform morphology by v-src-F172 $\Delta$ (Figure $4 \mathrm{~B}$; values representing the average of three experiments are given in Table 1) in the absence of a detectable increase in tyrosine phosphorylation of pp125 $5^{\mathrm{FAK}}$ (Figure $4 \mathrm{~A}$ ). Cells transformed to a round morphology by wt v-src or $\mathrm{v}$-src-Y416F had a twofold increase in kinase activity concomitant with increased $\mathrm{p} 125^{\mathrm{FAK}}$ phosphorylation. All increases in kinase activity were observed in both attached and suspended cells. In contrast, pp $125^{\mathrm{FAK}}$ kinase activity from cells expressing transformation-defective $\mathrm{v}$-src-F172 $\Delta / \mathrm{Y} 416 \mathrm{~F}$ was indistinguishable from that found in vector-only control cells.

In summary, increased pp $125^{\mathrm{FAK}}$ kinase activity can be dissociated from increased $\mathrm{pp} 125^{\mathrm{FAK}}$ tyrosine phosphorylation. Furthermore, increased p $125^{\mathrm{FAK}}$ kinase activity correlates with anchorage-independent growth, whereas increased tyrosine phosphorylation of pp $125^{\mathrm{FAK}}$ correlates with round, refractile morphological transformation.

\section{Phosphorylation and Subcellular Localization of Cortactin}

Given the intriguing results with the focal adhesion kinase, the phosphorylation state of the pp60 $60^{\mathrm{v}-s r c}$ substrate cortactin was examined. Cortactin is physically associated with the actin cytoskeleton (Wu and Parsons, 1993) and is phosphorylated primarily on serine and threonine residues in normal cells but becomes phosphorylated on tyrosine in cells transformed by pp60 ${ }^{\mathrm{c}-s r c-Y 527 \mathrm{~F}}$ (Wu et al., 1991). The level of tyrosine phosphorylation on cortactin was high in chicken cells expressing wt v-src and $\mathrm{v}-s r c-\mathrm{Y} 416 \mathrm{~F}$, significantly reduced in cells expressing v-src-F172 $\Delta$, and virtually undetectable in nontransformed cells expressing v-srcF172 $\Delta / Y 416 \mathrm{~F}$ (Figure 5A). In rat cells, cortactin was tyrosine phosphorylated in cells expressing wt v-src, and not in nontransformed cells expressing $\mathrm{v}$-srcF172 $\Delta$. 


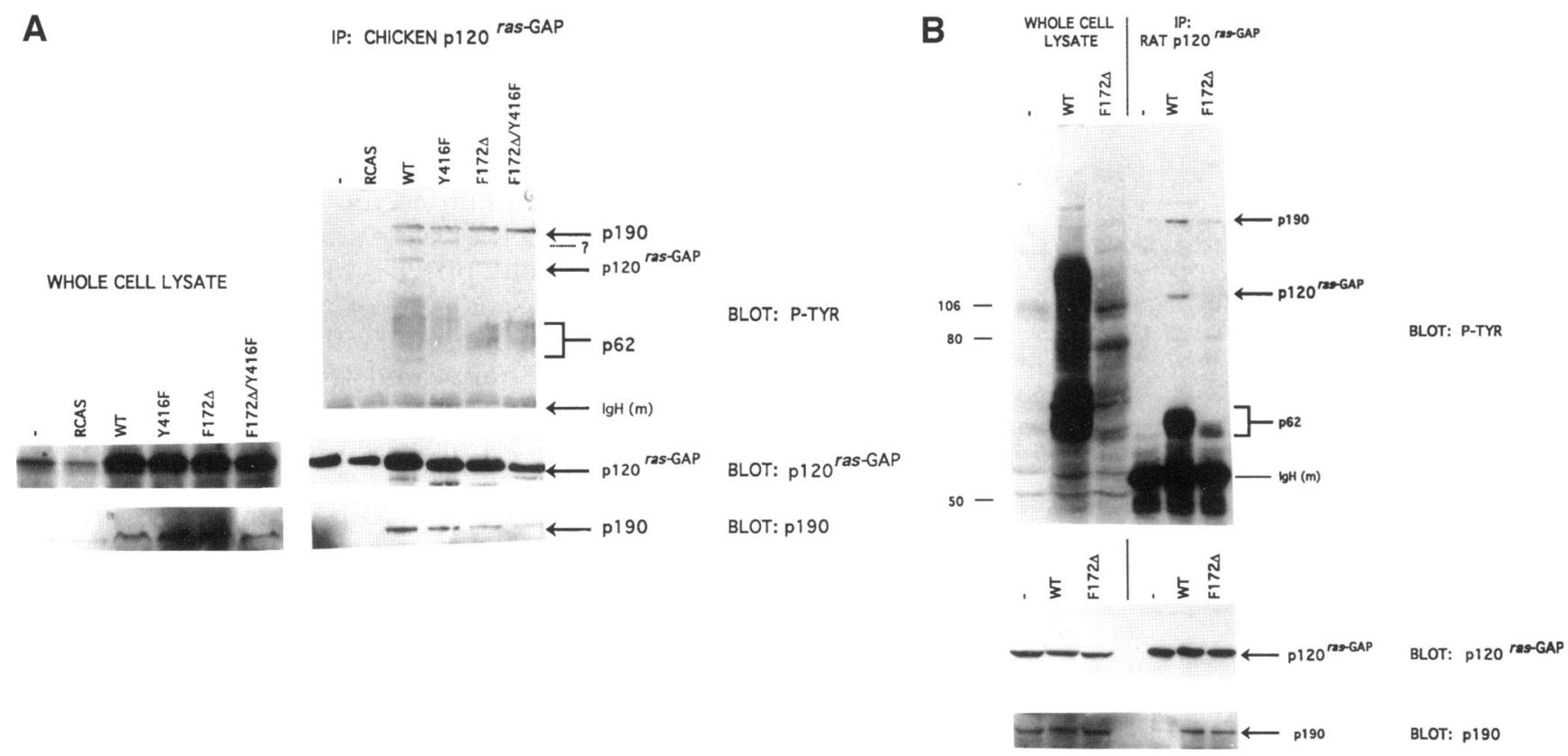

Figure 3. Tyrosine phosphorylation state of $\mathrm{p} 120^{\text {ras-GAP }}$ and $\mathrm{p} 120^{\text {ras-GAP }}$-associated proteins. GAP was immunoprecipitated from whole cell lysates of chicken cells $(\mathrm{A})$ or rat cells $(\mathrm{B})$ expressing various v-src alleles using B4F8 anti-p120 ras-GAP antibody. Proteins from whole cell lysates or from anti-p120 ras-GAP immunoprecipitates, as indicated, were separated on $7.5 \%$ polyacrylamide gels containing SDS and blotted to nitrocellulose. Proteins were detected by anti-p120 ras-GAP, anti-p190, or anti-P-Tyr antibodies as indicated. Representative blots are shown. The protein indicated by the question mark is currently unidentified. RCAS, chicken cells infected with vector only; "-", control rat cells.

In addition to tyrosine phosphorylation, subcellular localization of cortactin may be relevant to its role in transformation by $\mathrm{v}$-src. Cortactin is normally associated with actin filaments but in cells transformed by wt v-src, it is relocalized to large "podosome-like" patches (Wu et al., 1991). As expected, cortactin was localized to large patches in chicken cells expressing any of the transforming $\mathrm{v}$-src alleles (wt v-src, v-src-F172 $\Delta$, or v-src-Y416F; Figure 6). In contrast, localization of cortactin in cells expressing the nontransforming allele v-src$\mathrm{F} 172 \Delta / \mathrm{Y} 416 \mathrm{~F}$ was identical to its localization in mock or vector alone-transfected cells. In nontransformed rat cells expressing v-src-F172s, cortactin localization was indistinguishable from control Rat-1 cells, whereas cortactin in rat cells transformed by wt v-src relocalized to large patches. Thus expression of $\mathrm{v}$-src-F172 $\Delta$ reveals a correlation between cortactin relocalization, cortactin phosphorylation on tyrosine, and v-src transformation.

\section{pp60 ${ }^{v-s r c}$-associated PI3'K Activity}

All transforming alleles of $\mathrm{v}$-src encode proteins that associate with PI3'K activity (Fukui and Hanafusa, $1989,1991)$. Because studies using inhibitors of pp60 ${ }^{\mathrm{v}-s r c}$ activity imply pp60 $0^{\mathrm{v}-s r c}$-associated PI3'K activity may be essential for v-src transformation (Fukui and Hanafusa, 1989; Hamaguchi et al., 1993), levels of $\mathrm{pp} 60^{\mathrm{v}-s r c}$-associated PI3'K activity were determined (Figure 7 , values for the averages of three experiments are given in Table 1). Approximately sixto ninefold more $\mathrm{PI} 3^{\prime} \mathrm{K}$ activity was associated with immunoprecipitated $\mathrm{pp} 60^{\mathrm{v}-s r c}$ from chicken cells transformed to a round, refractile morphology (wt pp60 ${ }^{\mathrm{v}-s r c}$ and $\mathrm{pp} 60^{\mathrm{v}-s r c-Y 416 \mathrm{~F}}$ ) than with $\mathrm{pp} 60^{\mathrm{v}-s r c}$ from cells transformed to a fusiform morphology (pp60 ${ }^{\mathrm{v}-s r c-F 172 \Delta}$ ), or nontransformed cells (pp60v-src-F172 $/ \mathrm{Y} 416 \mathrm{~F}$ ). Thus round, refractile morphological transformation correlates with high levels of $\mathrm{pp} 60^{\mathrm{v}-s r c}$-associated PI3'K activity. Despite repeated efforts, PI3'K activity could not be reliably detected in association with wt pp60 ${ }^{\mathrm{v}-s r c}$ immunoprecipitated from rat cells (Verderame, unpublished results).

\section{DISCUSSION}

Since the discovery that $\mathrm{pp}^{\mathrm{v}} \mathrm{O}^{\mathrm{v}-\mathrm{src}}$ phosphorylates cellular proteins on tyrosine, the driving hypothesis has been that $\mathrm{pp} 60^{\mathrm{src}}$ transforms cells by directly phosphorylating a critical cellular substrate(s), thereby initiating a signal transduction cascade that eventually alters the growth regulatory apparatus of the cell. Despite extensive searches, this critical cellular substrate(s) has been elusive. Biochemical analysis of candidate substrates in cells transformed by mutant v-src alleles that induce partial transformed phenotypes, or in cells 
A

$\frac{\text { Detection }}{\text { Antibody }}$
$\alpha-$ P TYR
$\alpha-$ pp125fak
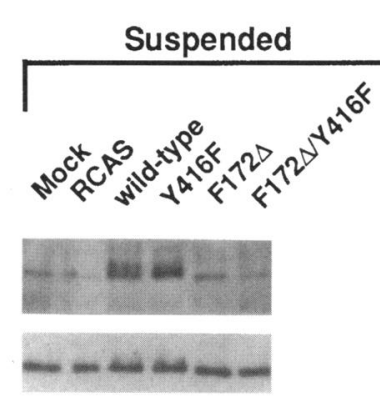

Attached

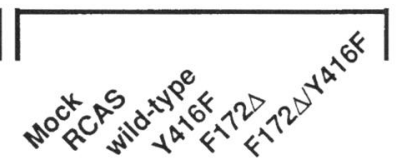

B

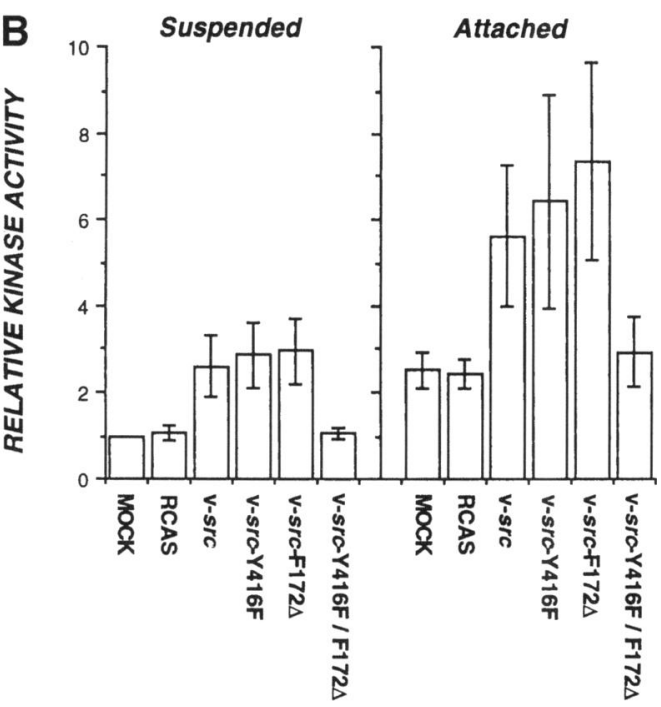

Figure 4. (A) Tyrosine phosphorylation of $\mathrm{pp} 125^{\mathrm{FAK}}$. Chicken cells expressing various v-src alleles were lysed after removal from the culture dish by trypsin treatment (suspended) or while still attached to the culture plate (attached). pp125 $5^{\text {FAK }}$ was immunoprecipitated from cell lysates using anti-FAK serum. Immunoprecipitated proteins were separated on $7.5 \%$ polyacrylamide gels containing SDS and blotted to nitrocellulose. Proteins were detected by anti-FAK serum or anti-P-Tyr antibodies. The experiment was performed three times with similar results; a representative experiment is shown. (B) pp125 $125^{\mathrm{FK}}$ kinase activity. Chicken cells expressing various v-src alleles were lysed after removal from the culture dish by trypsin treatment (suspended) or while still attached to the culture plate (attached). pp125 ${ }^{\mathrm{FAK}}$ was immunoprecipitated from these lysates and immune complex kinase assays were perforined using $\mathrm{E}_{4} \mathrm{Y}$ as the substrate. Reaction products were separated on $7.5 \%$ polyacrylamide gels containing SDS and the amount of ${ }^{32} \mathrm{P}$ incorporation was quantitated by scintillation counting. The experiment was performed three times; bars indicate standard error. The kinase activity of pp $125^{\mathrm{FAK}}$ from cells transformed by pp60 $0^{\mathrm{v}-\mathrm{sr}-\mathrm{F} 172 \Delta}$ is significantly different from control uninfected cells $(p<0.05$, Student's $t$-test). RCAS, chicken cells infected with vector only.

transformed by kinase-active but transformation-defective alleles of v-src has eliminated several potentially critical substrates from consideration (Parsons and Weber, 1989). The series of wt-transforming, hostrange, and transformation-defective v-src alleles used in this study provides a unique opportunity to explore the relevance of several putative $\mathrm{pp} 6 \mathrm{O}^{\mathrm{v}-s r c}$ substrates to $s r c$-mediated transformation because the $\mathrm{SH} 2$ domain mutant v-src-F172 $\Delta$ (unlike wt $\mathrm{pp}^{\mathrm{v}} \mathrm{v}^{\mathrm{v}-\mathrm{rrc}}$ ) transforms chicken but not rat cells. Additionally, transformation by this allele is dependent on autophosphorylation, thus providing an opportunity to examine the interplay of the SH2 domain, autophosphorylation, and substrate interactions. Results from this study are summarized in Table 1.

\section{The p21 ${ }^{\text {ras }}$ Pathway}

One biochemical pathway crucial for $s r c$-dependent transformation includes $\mathrm{p} 21^{\text {ras }}$; microinjection of neutralizing anti-p21 ${ }^{\text {ras }}$ antibodies into cells transformed by $\mathrm{pp} 60^{\mathrm{v}-s r c}$ reverses the transformed phenotype (Smith et al., 1986), which indicates p21 ${ }^{\text {ras }}$ acts downstream of $\mathrm{pp} 60^{\mathrm{v}-\mathrm{src}}$. Both positive-acting upstream activators (SHC), and downstream negative regulators (the ras-GTPase activating protein $\mathrm{p} 120^{\text {ras-GAP }}$ (reviewed in Pronk and Bos, 1994) are phosphorylated in $\mathrm{v}$-src-transformed cells. SHC tyrosine phosphoryla- tion recruits the $\mathrm{SH} 2$-containing adapter protein GRB2 into a complex with SHC (Rozakis-Adcock et al., 1992). GRB2 is complexed to the guanine nucleotide exchange factor SOS, the immediate upstream activator of p21 ras (Lowenstein et al., 1992; Buday and Downward, 1993; Egan et al., 1993; Gale et al., 1993; Li et al., 1993; Olivier et al., 1993; Rozakis-Adcock et al., 1993; Simon et al., 1993). Thus SHC phosphorylation indirectly activates $\mathrm{p} 21^{\text {ras }}$.

Results of this study are consistent with the important role SHC-phosphorylation serves in activating p $21^{\text {ras }}$. GRB2 was abundantly associated with phosphorylated SHC only in cells transformed by $\mathrm{v}$-src (independent of the morphological change induced or the level of SHC phosphorylation). Results with v-srcF172 $\Delta$ particularly strengthen this correlation; GRB2 abundantly associates with SHC in chicken cells transformed by v-src-F172 $\Delta$, but it is only barely detectable in rat cells that are not transformed by the same allele. SHC-dependent activation of $\mathrm{p} 21^{\text {ras }}$ requires GRB2 association (Rozakis-Adcock et al., 1992), and p21 ${ }^{\text {ras }}$ is required for $\mathrm{v}$-src-dependent transformation (Smith et al., 1986). Accordingly, results presented here are sufficient to explain host-dependent transformation by v-src-F172 , and identify SHC as a critical substrate for v-src-dependent transformation. 
A WHOLE CELL LYSATE IP: CHICKEN CORTACTIN
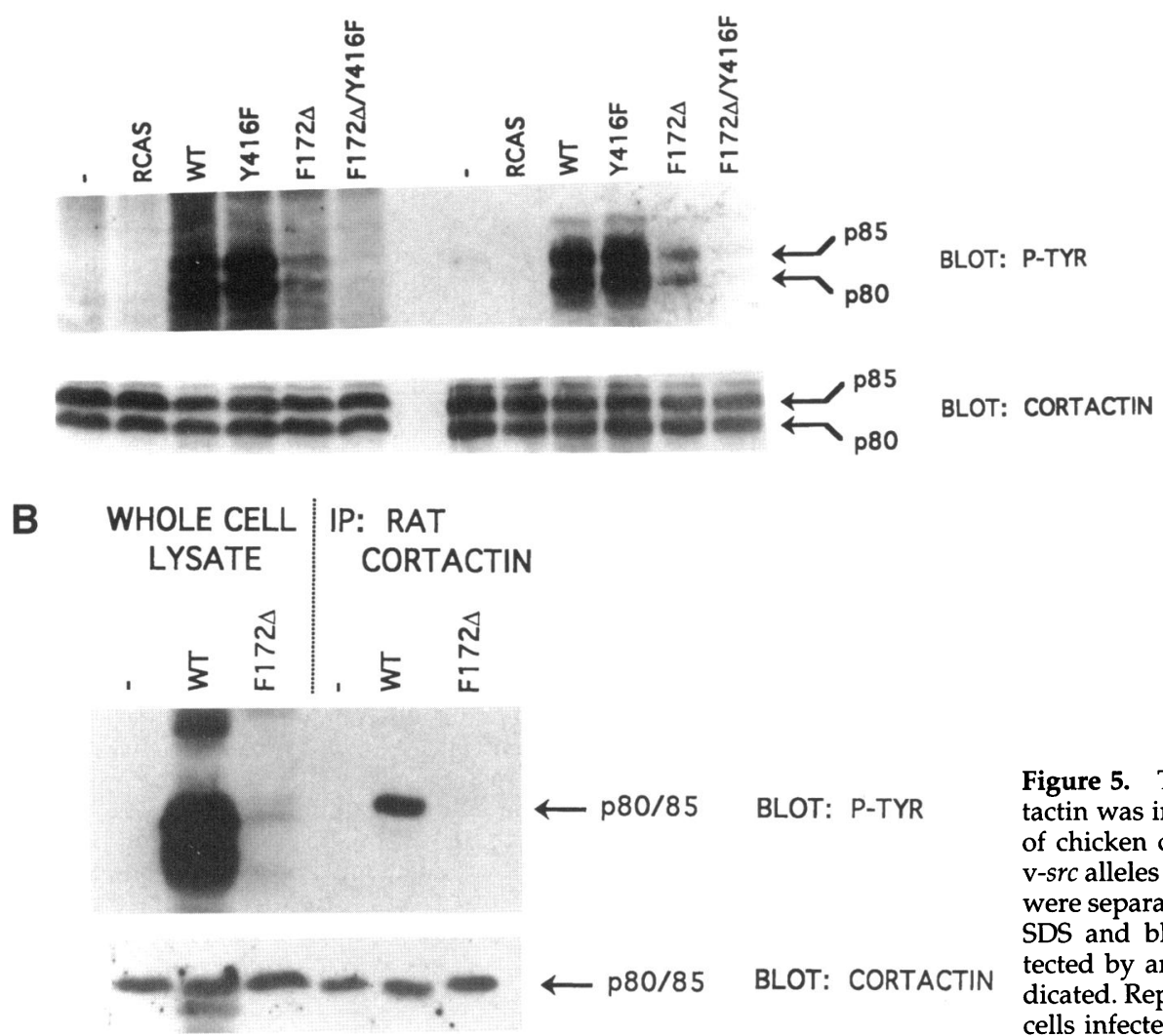

Figure 5. Tyrosine phosphorylation of cortactin. Cortactin was immunoprecipitated from whole cell lysates of chicken cells (A) or rat cells (B) expressing various v-src alleles using 4F11 anti-cortactin antibody. Proteins were separated on $7.5 \%$ polyacrylamide gels containing SDS and blotted to nitrocellulose. Proteins were detected by anti-cortactin or anti-P-Tyr antibodies as indicated. Representative blots are shown. RCAS, chicken cells infected with vector only; "-", control rat cells.

The biochemical basis for the differing SHC-GRB2 interaction between species is not clear. In particular, SHC was phosphorylated in chicken cells expressing the nontransforming allele $\mathrm{v}-\mathrm{src}-\mathrm{F} 172 \Delta /$ Y416F. SHC is known to be phosphorylated on multiple tyrosines in response to epidermal growth factor stimulation (Salcini et al., 1994), and presumably in v-src-transformed cells as well. pp60 $60^{\mathrm{v}-s r c-}$ F172 $/$ Y416F apparently cannot mediate the stable phosphorylation of the GRB2 binding site on SHC (presumably the Y317 homologue; Salcini et al., 1994). Phosphorylation of the GRB2 binding site in chicken SHC requires either $\mathrm{pp} 60^{\mathrm{v}-s r c}$ autophosphorylation or an intact pp $60^{\mathrm{v}-s r c} \mathrm{SH} 2$ domain; v-src alleles that retain one of these two features (v-srcF172 $\Delta$ or v-src-Y416F, respectively) are still transforming. This hypothesis is consistent with the observation that rat cells are not transformed by the $\mathrm{SH} 2$ domain mutant $\mathrm{pp} 60^{\mathrm{v}-\mathrm{src}-\mathrm{F} 172 \Delta}$, which is not autophosphorylated in rat cells (Oppermann et al., 1981; Verderame et al., 1989). A requirement for autophosphorylation or an intact $\mathrm{SH} 2$ domain could reflect an altered substrate specificity of autophosphorylated $\mathrm{pp} 60^{\mathrm{v}-s r c}$, decreased protection of the relevant SHC P-Tyr from phosphatase activity by the src SH2 domain, or a combination of these effects. An alternative possibility is that the $\mathrm{SH} 2$ domain and the autophosphorylation site participate in recruiting relevant proteins for phosphorylation by pp $60^{\mathrm{v}-s r c}$. These possibilities are obviously not mutually exclusive (see below). We have recently cloned the chicken homologue of SHC (Verderame, unpublished results) to address these questions.

p $21^{\text {ras }}$ is negatively regulated by $\mathrm{p} 120^{\text {ras-GAP }}$ (Trahey and Mccormick, 1987; Vogel et al., 1988; reviewed in Pronk and Bos, 1994). p120 ras-GAP is weakly bound to and phosphorylated by $\mathrm{pp} 60^{\mathrm{v}-s \mathrm{rc}}$ (Brott et al., 1991a,b). The role of tyrosine phosphorylation of $\mathrm{p} 120^{\text {ras-GAP }}$ in neoplastic transformation is controversial (Pronk and Bos, 1994). Results presented here indicate that $\mathrm{p} 120^{\text {ras-GAP }}$ tyrosine phosphorylation does not correlate with v-src transformation. Given recent evidence that $\mathrm{p} 120^{\text {ras-GAP }}$ is not the primary effector of $\mathrm{p} 21^{\text {ras }}$ (Stone et al., 1993), p120 ras-GAP may simply be an "innocent bystander," subject to phosphorylation along with many other cellular proteins in the presence of $\mathrm{pp} 60^{\mathrm{v}-s r c}$. If so, then phosphorylation of $\mathrm{p} 120^{\text {ras-GAP }}$ would be irrelevant for $s r c$-mediated transformation. 


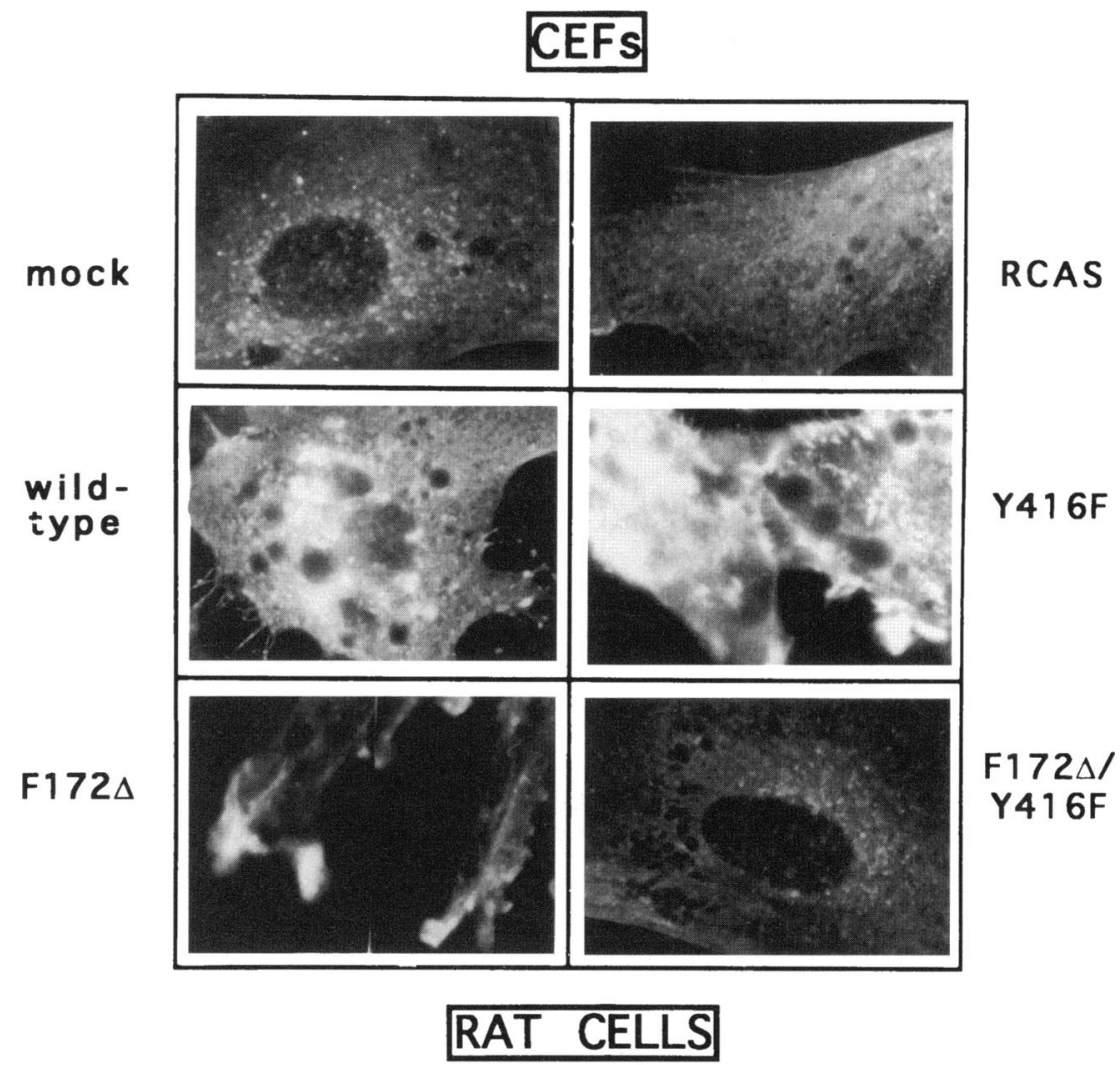

Figure 6. Indirect immunofluorescence of cortactin. Chicken and rat cells expressing v-src alleles were fixed in $3 \%$ paraformaldehyde and permeabilized with $0.4 \%$ Triton X-100. Cortactin was detected by indirect immunofluorescence with 4F11 anti-cortactin antibody. Cells representing the cortactin localization in the majority of cells in the given population are shown. The reason for brighter punctate staining in rat cells expressing $\mathrm{v}$-src-F172 $\Delta$ compared with control rat cells is unknown. RCAS, chicken cells infected with vector only.

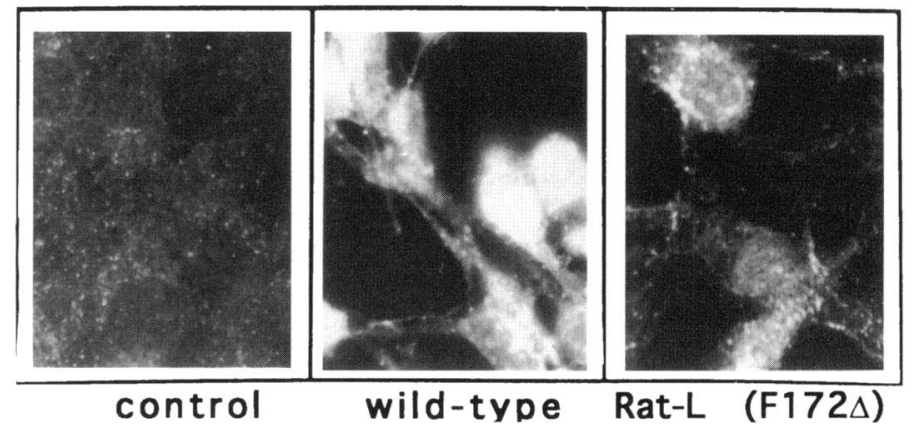

\section{$p p 125^{F A K}$}

A second protein implicated in src-mediated signal transduction is pp $125^{\mathrm{FAK}}$, a nonreceptor-PTK localized in focal adhesions (Hanks et al., 1992; Schaller et al., 1992), where wt pp60 ${ }^{\mathrm{v}-s r c}$ also concentrates (Rohrschneider, 1980). pp125 $5^{\mathrm{FAK}}$ tyrosine phosphorylation increases upon transformation by several PTKs (e.g. pp60 $0^{\mathrm{v}-s r}$ [Guan and Shalloway, 1992] and pp90 gag-yes [Kanner et al., 1990]), upon cellular attachment to extracellular matrix components (e.g. laminin, collagen type IV, vitronectin [Burridge et al., 1992; Hanks et al., 1992], or fibronectin [Guan et al., 1991; Kornberg et al., 1991; Guan and Shalloway, 1992; Hanks et al., 1992]), or by treatment with a wide variety of hormones including bradykinin or bombesin (Leeb-Lundberg and Song, 1993), vasopressin or endothelin (Zachary et al., 1992), and cholecystokinin-B/gastrin (Taniguchi et al., 1994). These results suggest that $\mathrm{pp} 125^{\mathrm{FAK}}$ is a point of convergence for a variety of extracellular signals (Zachary and Rozengurt, 1992). In normal cells, pp $125^{\mathrm{FAK}}$ is believed to serve an intracellular signaling role as well as participating in the organization of new focal adhesions (Burridge et al., 1992). Several pp $125^{\mathrm{FAK}}$ targets have been identified. GRB2 (Schlaepfer et al., 1994) and PI3'K (Chen and Guan, $1994 \mathrm{a}, \mathrm{b})$ physically associate with pp $125^{\mathrm{FAK}}$ after activation, whereas paxillin (Schaller and Parsons, 1995) and probably tensin (Bockholt and Burridge, 1993) are directly phosphorylated by $\mathrm{pp} 125^{\mathrm{FAK}}$. The functional significance of these interactions is currently unknown, however. In v-src-transformed cells, $\mathrm{pp} 125^{\mathrm{FAK}}$-associated kinase activity is increased 
Table 1. Summary of biochemical properties of chicken and rat cells expressing wt and mutant v-src alleles

\begin{tabular}{|c|c|c|c|c|c|c|c|c|c|c|}
\hline & \multirow[b]{2}{*}{$\mathrm{AIG}^{\mathrm{a}}$} & \multirow[b]{2}{*}{ Morph $^{b}$} & \multicolumn{2}{|c|}{$\mathrm{SHC}^{\mathrm{c}}$} & \multirow[b]{2}{*}{ ras-GAP ${ }^{d}$} & \multicolumn{2}{|c|}{$\mathrm{pp} 125^{\text {fak }} \mathrm{e}$} & \multicolumn{2}{|c|}{ Cortactin $^{f}$} & \multirow[b]{2}{*}{$\mathrm{P}^{1} 3^{\prime} \mathrm{KA}^{8}$} \\
\hline & & & P-tyr & GRB2 & & P-tyr & KA & P-tyr & IIF & \\
\hline \multicolumn{11}{|l|}{ Transformed $^{\text {h }}$} \\
\hline $\mathrm{v}$-src & + & round & + & + & + & + & $2.6(.7)$ & ++ & patchy & 1.00 \\
\hline $\mathrm{v}-s r c-\mathrm{Y} 416 \mathrm{~F}$ & + & round & + & + & + & + & $2.9(.8)$ & ++ & patchy & $.97(.22)$ \\
\hline $\mathrm{v}-s r c-\mathrm{F} 172 \Delta$ & + & fusiform & + & + & + & - & $3.0(.8)$ & + & patchy & $.16(.02)$ \\
\hline Rat & & & & & & & & & & \\
\hline $\begin{array}{c}\text { v-src } \\
\text { Nontransformed }\end{array}$ & + & round & + & + & + & $n d^{i}$ & nd & ++ & patchy & nd \\
\hline Chick & & & & & & & & & & \\
\hline $\mathrm{v}-\mathrm{src}-\mathrm{F} 172 \Delta / \mathrm{Y} 416 \mathrm{~F}$ & - & flat & + & - & + & - & $1.1(.1)$ & - & diffuse & $.11(.02)$ \\
\hline $\begin{array}{l}\text { Rat } \\
\text { v-src-F172 }\end{array}$ & - & flat & - & - & - & nd & nd & - & diffuse & nd \\
\hline
\end{tabular}

a Anchorage-independent growth ability (Verderame et al., 1989; Woods and Verderame, 1994).

b Morphology of cells expressing indicated v-src allele (Verderame et al., 1989; Woods and Verderame, 1994).

${ }^{c}$ Analysis of tyrosine phosphorylation state of SHC (P-tyr) or association of GRB2 with SHC (GRB2).

${ }^{\mathrm{d}}$ Tyrosine phosphorylation state of $\mathrm{p} 120^{\text {ras-GAP. }}$.

${ }^{\mathrm{e}}$ Analysis of tyrosine phosphorylation state (P-tyr) and $\mathrm{pp} 125^{\text {fak }}$-associated kinase activity (KA). Kinase activity is expressed relative to control uninfected chicken cells. Kinase activity is expressed relative to control (vector only) cells (average of three experiments; value in parentheses is standard error).

${ }^{\mathrm{f}}$ Tyrosine phosphorylation state (P-tyr) and subcellular distribution determined by indirect immunoflourescence (IIF) of cortactin.

${ }^{\mathrm{g}}$ pp60 $0^{\mathrm{v}-s r c}$-associated P13K activity. Kinase activity is expressed relative to wt pp60 ${ }^{\mathrm{v}-s r c}$ (average of three experiments; value in parentheses is standard error).

${ }^{\mathrm{h}}$ Cells transformed as a result of expression by the indicated $\mathrm{v}$-src allele.

${ }^{\mathrm{i}}$ Not determined.

${ }^{i}$ Cells not transformed by the expression of the indicated v-src allele.

(Schaller et al., 1992). This increase could be due to either increased pp $125^{\mathrm{FAK}}$ kinase activity, or associated pp60 $0^{\mathrm{v}-s r c}$ kinase activity.

The data presented here indicate that increased pp $125^{\text {FAK }}$ kinase activity correlates with $\mathrm{v}$-src-mediated transformation even though tyrosine-phosphorylation of pp $125^{\mathrm{FAK}}$ was not concomitantly increased in all cases. Apparently pp $60^{\mathrm{v}-s r c}$ can activate pp $125^{\mathrm{FAK}}$ by a means other than detectably increasing pp $125^{\mathrm{FAK}}$ tyrosine phosphorylation. Increased P-Tyr of pp $125^{\text {FAK }}$ in cells transformed by wt $\mathrm{pp} 60^{\mathrm{v}-\mathrm{src}}$ is due predominantly to autophosphorylation of Y397 on pp125 $5^{\mathrm{FAK}}$ (Cobb et al., 1994; Schaller et al., 1994). Other pp125 $5^{\mathrm{FAK}}$ tyrosines can be phosphorylated in vitro by pp60 ${ }^{\mathrm{v}-s r c}$ and are phosphorylated in vivo in cells expressing $\mathrm{pp} 60^{\mathrm{v}-s r c}$ (Calalb et al., 1995) resulting in a twofold increase in pp125 $5^{\mathrm{FAK}}$ kinase activity. What are the roles of these phosphorylated tyrosines in $\mathrm{src}$ mediated transformation? Phosphorylation of Y397 on pp $125^{\mathrm{FAK}}$ creates a high affinity binding site for the pp60 ${ }^{\text {sc }} \mathrm{SH} 2$ domain (phospho-YAEI) (Schaller et al., 1994) that is the first reported naturally occurring high affinity binding site identified for the $\mathrm{SH} 2$ domain of pp60 $0^{\mathrm{v}-s r c}$ (Songyang et al., 1993). Wt pp60 ${ }^{\mathrm{v}-s r c}$ is known to bind autophosphorylated $\mathrm{pp} 125^{\mathrm{FAK}}$ via the $\mathrm{pp} 60^{\mathrm{v}-s r c}$ $\mathrm{SH} 2$ domain (Cobb et al., 1994). The $\mathrm{SH} 2$ domain of pp60 $0^{\mathrm{v}-\mathrm{src}-\mathrm{F} 172 \Delta}$ cannot bind phosphorylated low affinity phosphopeptides (Woods and Verderame, 1994) or high affinity phosphopeptides (Verderame, unpublished results) and thus is predicted to be unable to bind autophosphorylated pp $125^{\mathrm{FAK}}$.

The loss of the pp60 $60^{\mathrm{v}-s r c}-\mathrm{pp} 125^{\mathrm{FAK}}$ interaction could provide an explanation for the lack of increased pp $125^{\mathrm{FAK}}$ phosphorylation in cells transformed by the host-range mutant $\mathrm{v}$-src-F172 $\Delta$. In these cells, decreased levels of P-Tyr may be a consequence of the failure of the pp $60^{\mathrm{v}-s r c-\mathrm{F} 172 \Delta}$ to protect phosphorylated Y397 from the action of cellular P-Tyr phosphatases; the $\mathrm{pp} 60^{\mathrm{v}-s r c} \mathrm{SH} 2$ domain can protect phosphorylated Y397 from dephosphorylation in vitro (Cobb et al., 1994). Failure of $\mathrm{pp} 60^{\mathrm{v}-s r c}$ to bind to $\mathrm{pp} 125^{\mathrm{FAK}}$ may have secondary consequences as well. Sites phosphorylated directly by pp60 $0^{\mathrm{v}-s r c}$ (Calalb et al., 1995) may not be phosphorylated efficiently if pp60 ${ }^{\mathrm{v}-s r c}$ does not bind $\mathrm{pp} 125^{\mathrm{FAK}}$. In addition to increasing $\mathrm{pp} 125^{\mathrm{FAK}}$ kinase activity, these P-tyr may allow other signaling molecules to interact with pp125 ${ }^{\mathrm{FAK}}$ (e.g. GRB2 [Schlaepfer et al., 1994] or PI3'K [Chen and Guan, 1994a,b]).

A second function of the pp60 ${ }^{\mathrm{v}-s r c}$-pp $125^{\mathrm{FAK}}$ interaction may be the precise localization of membranebound pp60 $0^{\mathrm{v}-s r c}$ to focal adhesions. Support for this idea derives from the observation that $\mathrm{pp} 60^{\mathrm{v}-s r c-\mathrm{F} 172 \Delta}$, 


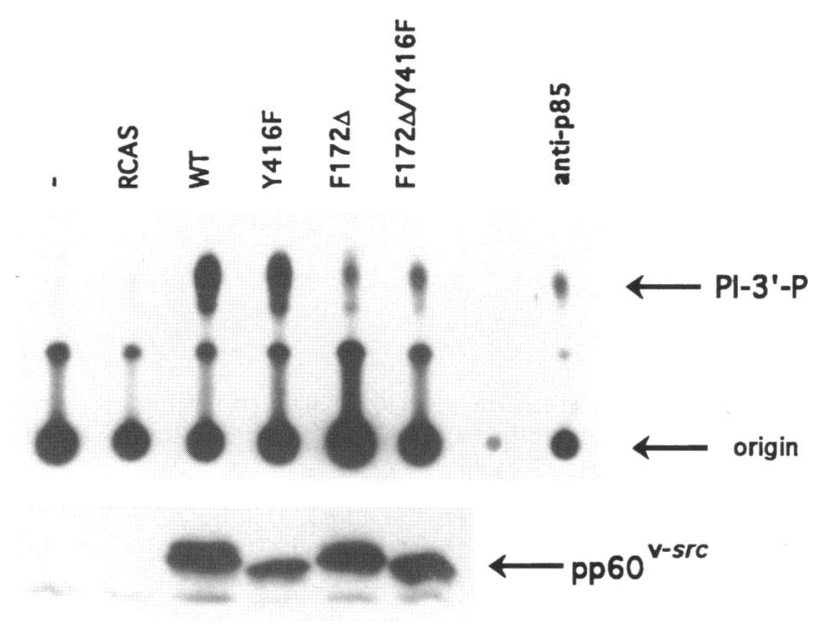

Figure 7. pp60 $60^{\mathrm{v}-s r c}$-associated $\mathrm{PI} 3^{\prime} \mathrm{K}$ activity. $\mathrm{pp} 60^{\mathrm{v}-\mathrm{src}}$ was immunoprecipitated from chicken cell lysates with monoclonal antibody 127. After washing, the immunoprecipitates were divided in half; one half was analyzed for $\mathrm{pp} 60^{\mathrm{v}-s r c}$ levels by protein blot, and the other half was subjected to PI3'K assay as described in MATERIALS AND METHODS. Extracted lipids were separated on silica plates in the presence of boric acid. Phosphorylated lipids were visualized by autoradiography. The amount of ${ }^{32} \mathrm{P}$ incorporation into the lipids was quantitated with the Betascope 603 analyzer. This experiment was repeated three times with similar results; a representative experiment is shown. RCAS, chicken cells infected with vector only.

whose SH2 domain cannot bind P-Tyr (Woods and Verderame, 1994), is not concentrated in focal adhesions (Rohrschneider and Reynolds, 1985). Of the transforming $\mathrm{pp} 60^{\mathrm{v}-s r c}$ proteins whose subcellular localization has been determined by indirect immunofluorescence, five different mutant alleles, including $\mathrm{v}$-src-F172 $\Delta$, encode proteins that do not concentrate in focal adhesions (Rohrschneider and Reynolds, 1985) and each of these five alleles induces a fusiform morphology. Many fusiform mutants (like v-src-F172 $\Delta$ ) map to SH2. Targeting of pp60 $0^{\mathrm{v}-s r c}$ to focal adhesions may be required for phosphorylation of focal adhesion or cytoskeletal components that regulate cellular morphology; however, targeting of pp $60^{\mathrm{v}-s r c}$ to focal adhesions may not be sufficient for full morphological transformation (Liebl and Martin, 1992).

\section{Cortactin}

Signal transduction molecules are not the only targets of $\mathrm{pp} 60^{\mathrm{v}-\mathrm{src}}$. Actin cytoskeletal organization is usually disrupted in neoplastically transformed cells, and a number of cytoskeleton-associated proteins are phosphorylated on tyrosine in $\mathrm{pp} 60^{\mathrm{v}-s r \mathrm{c}}$-transformed cells (Kellie et al., 1991). Cortactin is an actin-associated cytoskeletal protein (Wu and Parsons, 1993) that is phosphorylated primarily on serine and threonine residues in normal cells but becomes phosphorylated on tyrosine in cells expressing transforming variants of c-src ("activated" c-src) (Wu et al., 1991). Tyrosine phosphorylation of cortactin is apparently not sufficient to mediate $\mathrm{v}$-src transformation, however, because cortactin is phosphorylated on tyrosine in cells expressing nonmyristylated, activated $\mathrm{pp} 60^{\mathrm{c}-s r c}(\mathrm{Wu}$ et al., 1991). In cells transformed by activated $p p 60^{c-s r c}$, cortactin relocalizes from along F-actin filaments to podosomes (Wu et al., 1991; Wu and Parsons, 1993).

Results presented here show that cortactin phosphorylation is reduced in chicken cells transformed to a fusiform morphology, and virtually undetectable in rat or chicken cells expressing nontransforming alleles of $\mathrm{v}$-src. In all cells expressing transforming alleles of $\mathrm{v}$-src, including chicken cells with reduced tyrosine phosphorylation and fusiform morphology, cortactin is relocalized to focal adhesion-like structures ("podosomes"; Wu et al., 1991; Wu and Parsons, 1993). Both cortactin relocalization (this study) and actin cytoskeletal disruption (Verderame et al., 1989; Woods and Verderame, 1994) correlate with v-src-mediated transformation. Further studies will be required to determine whether cortactin relocalization is a cause or a consequence of the disrupted actin cytoskeleton seen in v-src-transformed cells.

\section{PI3'K}

Cells transformed by v-src or src-related kinases (v-yes and $\mathrm{v}-f p s$ ) contain elevated levels of phosphotidylinositol-3,4-bisphosphate and phosphotidylinositoltrisphosphate (Fukui et al., 1991), suggesting that these PTKs alter the regulation of PI3'K activity (see Fry, 1994; Kapeller and Cantley, 1994 for a review of PI3'K). Phosphotidylinositol-3,4-bisphosphate can serve as a potent activator of protein kinase C $-\delta,-\epsilon$, and $-\eta$ (Toker et al., 1994), which can provide additional downstream signals. Activation of PI3'K occurs by stabilization of an altered conformation induced by upstream signaling proteins binding to the regulatory protein p85 (Panayotou et al., 1992; Pleiman et al., 1994). All 10 of the transforming src variants tested by Fukui and Hanafusa associated with PI3'K (Fukui and Hanafusa, 1989). This interaction is not sufficient for transformation, however, because PI3' $\mathrm{K}$ has been shown to associate with two transformation-defective proteins: nonmyristylated $\mathrm{pp} 60^{\mathrm{v}-s r c}$ and kinaseinactive pp60 ${ }^{\mathrm{v}-s r c}$ (Fukui and Hanafusa, 1989). Inhibition of $\mathrm{v}$-src transformation by herbimycin A inhibited $\mathrm{pp} 60^{\mathrm{v}-s r c}$ ability to associate with PI3'K (Hamaguchi et al., 1993). Collectively, these data are consistent with the hypothesis that a molecular interaction between $\mathrm{pp} 60^{\mathrm{v}-s r c}$ and $\mathrm{PI} 3^{\prime} \mathrm{K}$ is necessary but not sufficient for $\mathrm{v}$-src transformation.

The amount of pp60 $60^{\mathrm{v}-s r c}$-associated PI3'K activity was decreased approximately sixfold in cells transformed by $\mathrm{pp} 60^{\mathrm{v}-\mathrm{src}-\mathrm{F} 172 \Delta}$ compared with the wt pp $60^{\mathrm{v}-s \mathrm{rc}}$ control, and this value was not further 
decreased by blocking pp $60^{\mathrm{v}-s r c}$ autophosphorylation and abolishing transformation. Although the SH3 domain is the primary site of interaction between $\mathrm{pp} 60^{\mathrm{v}-s r c}$ and the $\mathrm{PI}^{\prime} \mathrm{K}$ p85 regulatory subunit (Liu et al., 1993), the SH2 domain contributes to the formation of the complex (Fukui and Hanafusa, 1991; Liu et al., 1993). The results presented here confirm that observation, because $\mathrm{pp} 60^{\mathrm{v}-s r c}$-associated PI3' $\mathrm{K}$ activity is reduced but not eliminated in cells transformed by the $\mathrm{SH} 2$ mutant allele v-srcF172 $\Delta$. Clearly the regulation of PI3'K activity by pp60 ${ }^{\mathrm{v}-s r c}$ is complex; the recent report suggesting the potential for indirect regulation of $\mathrm{PI} 3^{\prime} \mathrm{K}$ by pp60 $0^{\mathrm{v}-s r c}$ (via ras) adds to that complexity (Rodriguez-Viciana et al., 1994).

Four other v-src alleles inducing fusiform morphology have been examined previously for associated PI3'K activity (Fukui and Hanafusa, 1989, 1991). Like pp60 ${ }^{\mathrm{v}-s r c-F 172 \Delta}$, each of the four proteins associates with less PI3'K activity than wt pp60 ${ }^{\mathrm{v}-s r c}$. One of these mutations effects only amino acids in the SH3 domain, but the other three effect residues exclusively within $\mathrm{SH} 2$, again emphasizing the cooperative nature of $\mathrm{SH} 2$ and $\mathrm{SH} 3$ in binding the regulatory subunit of $\mathrm{PI} 3^{\prime} \mathrm{K}$. These results raise the possibility that high levels of associated PI3'K activity are required for full morphological transformation. Although fusiform morphological transformation has been correlated with decreased PI3'K activity (Fukui and Hanafusa, 1989, 1991) and separately with localization of $\mathrm{pp} 60^{\mathrm{v}-s r c}$ outside of focal adhesions (Rohrschneider and Reynolds, 1985), v-src-F172 $\Delta$ is the first allele whose encoded protein has had both properties measured. Given that localization of $\mathrm{pp} 60^{\mathrm{v}-s r c}$ to focal adhesions (perhaps via pp $125^{\mathrm{FAK}}$ interaction; see above) and high levels of PI3'K-associated activity both correlate with full morphological transformation when tested with a single allele, one can now envision attempts to separately restore one or the other property and determine the effects on morphological transformation. The details of PI3' $\mathrm{K}$ activation in $\mathrm{v}$-src-transformed cells is further complicated because PI3' $\mathrm{K}$ activity is also associated with activated pp125 $5^{\mathrm{FAK}}$ (Chen and Guan, 1994a,b).

In summary, increased association of GRB2 with tyrosine phosphorylated SHC, and not $\mathrm{pp}^{\mathrm{v}} \mathrm{v}^{\mathrm{v}-\mathrm{src}} \mathrm{ki}-$ nase activity, SHC phosphorylation level, or $\mathrm{pp} 60^{\mathrm{v}-s r c}$ associated $\mathrm{PI}^{\prime} \mathrm{K}$ activity correlated with anchorageindependent growth in both rat and chicken cells. In chicken cells, the SHC/GRB2 interaction requires either an intact $\mathrm{SH} 2$ domain, or autophosphorylation of pp $60^{\mathrm{v}-s r c}$. Additionally, increased $\mathrm{pp} 125^{\mathrm{FAK}}$ and increased $\mathrm{pp} 6 \mathrm{O}^{\mathrm{v}-s r c}$-associated $\mathrm{PI} 3^{\prime} \mathrm{K}$ activity specifically correlated with round refractile morphological transformation in chicken cells, and requires an intact $\mathrm{SH} 2$ domain, but not autophosphorylation.

\section{ACKNOWLEDGMENTS}

We thank Tom Parsons, Sally Parsons, and Joan Brugge for antibodies essential for this work; John Wills, David Spector, Doyle Seiver, and Judy Tevethia for critical reading of the manuscript; and John Wills and David Spector for many useful discussions. This work was supported by research grants from the National Institutes of Health (CA-52791 to M.F.V. and GM48050 to J.-L.G.).

\section{REFERENCES}

Bockholt, S.M., and Burridge, K. (1993). Cell spreading on extracellular matrix proteins induces tyrosine phosphorylation of tensin. J. Biol. Chem. 268, 14565-14567.

Brott, B.K., Decker, G., Shafer, J., Gibbs, J.B., and Jove, R. (1991a). GTPase-activating protein interactions with the viral and cellular Src kinases. Proc. Natl. Acad. Sci. USA 88, 755-759.

Brott, B.K., Decker, S., Obrien, M.C., and Jove, R. (1991b). Molecular features of the viral and cellular Src kinases involved in interactions with the GTPase-activating protein. Mol. Cell. Biol. 11, 5059-5067.

Buday, L., and Downward, J. (1993). Epidermal growth factor regulates p21 ras through the formation of a complex of receptor, Grb2 adapter protein, and Sos nucleotide exchange factor. Cell 73, 611620 .

Burridge, K., Turner, C.E., and Romer, L.H. (1992). Tyrosine phosphorylation of paxillin and pp $125^{\mathrm{FAK}}$ accompanies cell adhesion to extracellular matrix: a role in cytoskeletal assembly. J. Cell. Biol. 119, 893-903.

Calalb, M.B., Polte, T.R., and Hanks, S.K. (1995). Tyrosine phosphorylation of focal adhesion kinase at sites in the catalytic domain regulates kinase activity: a role for Src family kinases. Mol. Cell. Biol. 15, 954-963.

Chen, H.C., and Guan, J.L. (1994a). Association of focal adhesion kinase with its potential substrate phosphatidylinositol 3-kinase. Proc. Natl. Acad. Sci. USA 91, 10148-10152.

Chen, H.C., and Guan, J.L. (1994b). Stimulation of phosphatidylinositol 3 '-kinase association with focal adhesion kinase by plateletderived growth factor. J. Biol. Chem. 269, 31229-31233.

Cobb, B.S., Schaller, M.D., Leu, T.-H., and Parsons, J.T. (1994). Stable association of pp60src and pp59 fyn with the focal adhesion-associated protein tyrosine kinase, pp125 fak. Mol. Cell. Biol. 14, 147-155.

Crowe, A.J., McGlade, J., Pawson, T., and Hayman, M.J. (1994). Phosphorylation of the SHC proteins on tyrosine correlates with the transformation of fibroblasts and erythroblasts by the vsea tyrosine kinase. Oncogene 9, 537-544.

Egan, S.E., Giddings, B.W., Brooks, M.W., Buday, L., Sizeland, A.M., and Weinberg, R.A. (1993). Association of Sos Ras exchange protein with Grb2 is implicated in tyrosine kinase signal transduction and transformation. Nature 363, 45-51.

Fry, M.J. (1994). Structure, regulation and function of phosphoinositide 3-kinases. Biochim. Biophys. Acta 1226, 237-268.

Fukui, Y., and Hanafusa, H. (1989). Phosphatidylinositol kinase activity associates with viral $\mathrm{pp} 60^{\text {src }}$ protein. Mol. Cell. Biol. 9, 1651-1658.

Fukui, Y., and Hanafusa, H. (1991). Requirement of phosphatidylinositol-3 kinase modification for its association with $\mathrm{pp}^{\mathrm{s}} \mathrm{0}^{\text {src }}$. Mol. Cell. Biol. 11, 1972-1979.

Fukui, Y., Saltiel, A.R., and Hanafusa, H. (1991). Phosphatidylinositol-3 kinase is activated in v-src, v-yes, and v-fps transformed chicken embryo fibroblasts. Oncogene $6,407-411$. 
Gale, N.W., Kaplan, S., Lowenstein, E.J., Schlessinger, J., and BarSagi, D. (1993). Grb2 mediates the EGF-dependent activation of guanine nucleotide exchange on Ras. Nature 363, 88-92.

Guan, J.-L., and Shalloway, D. (1992). Regulation of focal adhesionassociated protein tyrosine kinase by both cellular adhesion and oncogenic transformation. Nature 358, 690-693.

Guan, J.L., Trevithick, J.E., and Hynes, R.O. (1991). Fibronectin/ integrin interaction induces tyrosine phosphorylation of a $120-\mathrm{kDa}$ protein. Cell Regul. 2, 951-964.

Hamaguchi, M., Xiao, H., Uehara, Y., Ohnishi, Y., and Nagai, Y. (1993). Herbimycin A inhibits the association of $\mathrm{pp} 60^{\mathrm{v}-s r c}$ with the cytoskeletal structure and with phosphotidylinositol $3^{\prime}$ kinase. Oncogene 8, 559-564.

Hanks, S.K., Calalb, M.B., Harper, M.C., and Patel, S.K. (1992). Focal adhesion protein-tyrosine kinase phosphorylated in response to cell attachment to fibronectin. Proc. Natl. Acad. Sci. USA 89, 8487-8491.

Hughes, S.H., Greenhouse, J.J., Petropoulos, C.J., and Sutrave, P. (1987). Adapter plasmids simplify the insertion of foreign DNA into helper-independent retroviral vectors. J. Virol. 61, 3004-3012.

Kanner, S.B., Reynolds, A.B., Vines, R.R., and Parsons, J.T. (1990). Monoclonal antibodies to individual tyrosine-phosphorylated protein substrates of oncogene-encoded tyrosine kinases. Proc. Natl. Acad. Sci. USA 87, 3328-3332.

Kapeller, R., and Cantley, L.C. (1994). Phosphatidylinositol 3-kinase. Bioessays 16, 565-576.

Kellie, S., Horvath, A.R., and Elmore, M.A. (1991). Cytoskeletal targets for oncogenic tyrosine kinases. J. Cell. Sci. 99, 207-211.

Koch, C.A., Anderson, D., Moran, M.F., Ellis, C., and Pawson, T. (1991). SH2 and SH3 domains: elements that control interactions of cytoplasmic signaling proteins. Science 252, 668-674.

Kornberg, L.J., Earp, H.S., Turner, C.E., Prockop, C., and Juliano, R.L. (1991). Signal transduction by integrins: increased protein tyrosine phosphorylation caused by clustering of beta-1 integrins. Proc. Natl. Acad. Sci. USA 88, 8392-8396.

Leeb-Lundberg, L.M.F., and Song, X. (1993). Identification of p125, a component of a group of $120-\mathrm{kDa}$ proteins that are phosphorylated on tyrosine residues in response to bradykinin and bombesin stimulation in anti-Ras-GTPase-activating protein immunoprecipitates of Swiss 3T3 cells. J. Biol. Chem. 268, 8151-8157.

Li, N., Batzer, A., Daly, R., Yajnik, V., Skolnik, E., Chardin, P., Bar-Sagi, D., Margolis, B., and Schlessinger, J. (1993). Guaninenucleotide-releasing factor hSos1 binds to Grb2 and links receptor tyrosine kinases to Ras signalling. Nature 363, 85-88.

Liebl, E.C., and Martin, G.S. (1992). Intracellular targeting of pp60 ${ }^{\text {src }}$ expression: localization of $\mathrm{v}$-src to adhesion plaques is sufficient to transform chicken embryo fibroblasts. Oncogene 7, 2417-2428.

Liu, X., Marengere, L.E.M., Koch, C.A., and Pawson, T. (1993). The v-Src SH3 domain binds phosphotidylinositol 3'-kinase. Mol. Cell. Biol. 13, 5225-5232.

Lowenstein, E.J., Daly, R.J., Batzer, A.G., Li, W., Margolis, B., Lammers, R., Ullrich, A., Skolnik, E.Y., Bar-Sagi, D., and Schlessinger, J. (1992). The SH2 and SH3 domain-containing protein GRB2 links receptor tyrosine kinases to Ras signaling. Cell 70, 431-442.

McGlade, J., Cheng, A., Pelicci, G., Pelicci, P.G., and Pawson, T. (1992). Shc proteins are phosphorylated and regulated by the v-Src and v-Fps protein tyrosine kinases. Proc. Natl. Acad. Sci. USA 89, 8869-8873.

Moran, M.F., Polakis, P., Mccormick, F., Pawson, T., and Ellis, C. (1991). Protein tyrosine kinases regulate the phosphorylation, protein interactions, subcellular distribution, and activity of $\mathrm{p}^{2} 1^{\text {ras }} \mathrm{GTP}$ ase-activating protein. Mol. Cell. Biol. 11, 1804-1812.
Olivier, J.P., Raabe, T., Henkemeyer, M., Dickson, B., Mbamalu, G., Margolis, B., Schlessinger, J., Hafen, E., and Pawson, T. (1993). A Drosophila SH2-SH3 adapter protein implicated in coupling the sevenless tyrosine kinase to an activator of Ras guanine nucleotide exchange, Sos. Cell 73, 179-191.

Oppermann, H., Levinson, A.D., and Varmus, H.E. (1981). The structure and protein kinase activity of proteins encoded by nonconditional mutants and back mutants in the src gene of avian sarcoma virus. Virology 108, 47-70.

Panayotou, G., Federwisch, M., Wroblowski, B., Dhand, R., Fry, M.J., Blundell, T.L., Wollmer, A., and Waterfield, M.D. (1992). Interaction of the p85 subunit of PI 3-kinase and its N-terminal SH2 domain with a PDGF receptor phosphorylation site: structural features and analysis of conformational changes. EMBO J. 11, 42614272.

Parker, R.C., Varmus, H.E., and Bishop, J.M. (1984). Expression of $v$-src and chicken c-src in rat cells demonstrates qualitative differences between pp60 ${ }^{\mathrm{v}-s r c}$ and pp60 $0^{\mathrm{c}-s r c}$. Cell 37, 131-139.

Parsons, J.T., and Weber, M.J. (1989). Genetics of $s r c$, structure and functional organization of a protein tyrosine kinase. Curr. Top. Microbiol. Immunol. 147, 79-127.

Pleiman, C.M., Hertz, W.M., and Cambier, J.C. (1994). Activation of phosphatidylinositol- $3^{\prime}$ kinase by SRC-family kinase Sh3 binding to the P85 subunit. Science 263, 1609-1612.

Pronk, G.J., and Bos, J.L. (1994). The role of p21 ras in receptor tyrosine kinase signalling. Biochim. Biophys. Acta. 1198, 131-147.

Pronk, G.J., Polakis, P., Wong, G., Devriessmits, A.M.M., Bos, J.L., and Mccormick, F. (1992). Association of a tyrosine kinase activity with GAP complexes in v-src-transformed fibroblasts. Oncogene 7 , 389-394.

Rodriguez-Viciana, P., Warne, P.H., Dhand, R., Vanhaesebroeck, B., Gout, I., Fry, M.J., Waterfield, M.D., and Downward, J. (1994). Phosphatidylinositol-3-OH kinase as a direct target of Ras. Nature $370,527-532$.

Rohrschneider, L., and Reynolds, S. (1985). Regulation of cellular morphology by the Rous sarcoma virus src gene: analysis of fusiform mutants. Mol. Cell. Biol. 5, 3097-3107.

Rohrschneider, L.R. (1980). Adhesion plaques of Rous sarcoma virus-transformed cells contain the src gene product. Proc. Natl. Acad. Sci. USA 77, 3514-3518.

Rozakis-Adcock, M., Fernley, R., Wade, J., Pawson, T., and Bowtell, D. (1993). The SH2 and SH3 domains of mammalian Grb2 couple the EGF receptor to the Ras activator Msos1. Nature 363, 83-85.

Rozakis-Adcock, M., McGlade, J., Mbamalu, G., Pelicci, G., Daly, R., Li, W., Batzer, A., Thomas, S., Brugge, J., Pelicci, P.G., Schlessinger J., and Pawson, T. (1992). Association of the Shc and Grb2/Sem5 SH2-containing proteins is implicated in activation of the Ras pathway by tyrosine kinases. Nature 360, 689-692.

Salcini, A.E., McGlade, J., Pelicci, G., Nicoletti, I., Pawson, T., and Pelicci, P.G. (1994). Formation of Shc-Grb2 complexes is necessary to induce neoplastic transformation by overexpression of Shc proteins. Oncogene 9, 2827-2836.

Schaller, M.D., Borgman, C.A., Cobb, B.S., Vines, R.R., Reynolds, A.B., and Parsons, J.T. (1992). pp $125^{\mathrm{FAK}}$, a structurally distinctive protein-tyrosine kinase associated with focal adhesions. Proc. Natl. Acad. Sci. USA 89, 5192-5196.

Schaller, M.D., Hildebrand, J.D., Shannon, J.D., Fox, J.W., Vines, R.R., and Parsons, J.T. (1994). Autophosphorylation of the focal adhesion kinase, pp125(Fak), directs Sh2-dependent binding of pp60(SRC). Mol. Cell. Biol. 14, 1680-1688. 
Schaller, M.D., and Parsons, J.T. (1995). pp125 $125^{\mathrm{FAK}}$-dependent tyrosine phosphorylation of paxillin creates a high affinity binding site for Crk. Mol. Cell. Biol. 15, 2635-2645.

Schlaepfer, D.D., Hanks, S.K., Hunter, T., and van der Geer, P. (1994). Integrin-mediated signal transduction linked to Ras pathway by GRB2 binding to focal adhesion kinase. Nature 372, 786-791.

Simon, M.A., Dodson, G.S., and Rubin, G.M. (1993). An SH3-SH2SH3 protein is required for p21(Ras1) activation and binds to sevenless and Sos proteins in vitro. Cell 73, 169-177.

Smith, M.R., DeGudicibus, S.J., and Stacey, D.W. (1986). Requirement for c-ras proteins during viral oncogene transformation. $\mathrm{Na}$ ture $320,540-543$.

Songyang, Z., Shoelson, S.E., Chaudhuri, M., Gish, G., Pawson, T., Haser, W.G., King, F., Roberts, T., Ratnofsky, S., Lechleider, R.J., Neel, B.G., Birge, R.B., Fajardo, J.E., Chou, M.M., Hanafusa, H., Schaffhausen, B., and Cantley, L.C. (1993). SH2 domains recognize specific phosphopeptide sequences. Cell 72, 767-778.

Stone, J.C., Colleton, M., and Bottorff, D. (1993). Effector domain mutations dissociate p21 $1^{\text {ras }}$ effector function and GTPase-activating protein interaction. Mol. Cell. Biol. 13, 7311-7320.

Taniguchi, T., Matsui, T., Mitsuhiro, I., Murayama, T., Tsukamoto, T., Katakami, K., Chiba, T., and Chihara, K. (1994). Cholecystokinin$\mathrm{B} /$ gastrin receptor signaling pathway involves tyrosine phosphorylations of $\mathrm{p}^{25^{\mathrm{fak}}}$ and $\mathrm{p} 42^{\mathrm{map}}$. Oncogene 9, 861-867.

Toker, A., Meyer, M., Reddy, K.K., Falck, J.R., Aneja, R., Aneja, S., Parra, A., Burns, D.J., Ballas, L.M., and Cantley, L.C. (1994). Activation of protein kinase $C$ family members by the novel polyphosphoinositides PtdIns-3,4- $\mathrm{P}_{2}$ and PtdIns-3,4,5- $\mathrm{P}_{3}$. J. Biol. Chem. 269, 32358-32367.

Trahey, M., and Mccormick, F. (1987). A cytoplasmic protein stimulates normal N-ras p21 GTPase, but does not effect oncogenic mutants. Science 238, 542-545.

Varmus, H.E., Quintrell, N., and Wyke, J. (1981). Revertants of an ASV-transformed rat cell line have lost the complete provirus or sustained mutations in src. Virology 108, 28-46.

Verderame, M.F., Kaplan, J.M., and Varmus, H.E. (1989). A mutation in v-src that removes a single conserved residue in the SH-2 domain of $\mathrm{pp} 60^{\mathrm{v}-\mathrm{src}}$ restricts transformation in a host-dependent manner. J. Virol. 63, 338-348.
Verderame, M.F., and Varmus, H.E. (1994). Highly conserved amino acids in the $\mathrm{SH} 2$ and catalytic domains of $\mathrm{v}$-src are altered in naturally occurring, transformation-defective alleles. Oncogene 9, 175-182.

Vogel, U.S., Dixon, R.A.F., Schaber, M.D., Diehl, R.E., Marshall, M.S., Scolnick, E.M., Sigal, I.S., and Gibbs, J.B. (1988). Cloning of bovine GAP and its interaction with oncogenic ras. Nature 335, 90-93.

Waksman, G., Kominos, D., Robertson, S.C., Pant, N., Baltimore, D., Birge, R.B., Cowburn, D., Hanafusa, H., Mayer, B.J., Overduin, M., Resh, M.D., Rios, C.B., Silverman, L., and Kuriyan, J. (1992). Crystal structure of the phosphotyrosine recognition domain SH2 of v-src complexed with tyrosine-phosphorylated peptides. Nature 358, 646-653.

Walsh, J.P., Caldwell, K.K., and Majerus, P.W. (1991). Formation of phosphotidylinositol 3-phosphate by isomerization from phosphotidylinositol 4-phosphate. Proc. Natl. Acad. Sci. USA 88, 9184-9187.

Woods, K.M., and Verderame, M.F. (1994). Autophosphorylation is required for high kinase activity and efficient transforming ability of proteins encoded by host-range alleles of v-src. J. Virol. $68,7267-$ 7274 .

Wu, H., and Parsons, J.T. (1993). Cortactin, an 80/85-kilodalton pp $60^{\text {src }}$ substrate, is a filamentous actin-binding protein enriched in the cell cortex. J. Cell Biol. 120, 1417-1426.

$\mathrm{Wu}$, H., Reynolds, A.B., Kanner, S.B., Vines, R.R., and Parsons, J.T. (1991). Identification and characterization of a novel cytoskeletonassociated pp60 $0^{\text {src }}$ substrate. Mol. Cell. Biol. 11, 5113-5124.

Xing, Z., Chen, H.C., Nowlen, J.K., Taylor, S.J., Shalloway, D., and Guan, J.L. (1994). Direct interaction of v-Src with the focal adhesion kinase mediated by the Src SH2 domain. Mol. Biol. Cell. 5, 413-421.

Zachary, I., and Rozengurt, E. (1992). Focal adhesion kinase ( $\mathrm{p} 125(\mathrm{FAK})$ ): a point of convergence in the action of neuropeptides, integrins, and oncogenes. Cell 71, 891-894.

Zachary, I., Sinnettsmith, J., and Rozengurt, E. (1992). Bombesin, vasopressin, and endothelin stimulation of tyrosine phosphorylation in Swiss 3T3 cells: identification of a novel tyrosine kinase as a major substrate. J. Biol. Chem. 267, 19031-19034. 